\title{
Teaching Innovation with the Film 'Objectified'
}

\section{Daniel Forbes (University of Minnesota)}

I'd like to recommend the film Objectified (https://vimeo.com/ondemand/objectified) as a useful resource for people teaching and studying entrepreneurship.

Objectified is a feature-length documentary film released in 2009. The film examines the role of tangible, non-living everyday objects - from chairs to computers to toothbrushes - and the people who design them. The film is directed by Gary Hustwit and is part of a trilogy of design-related films Hustwit has produced. The film is instructive in at least two key ways relevant to entrepreneurship. First, it includes behind-the-scenes coverage of product development work at the wellknown design firm IDEO. In one segment, for example, a group of designers engage in "ideation" (or idea creation) in an effort to identify new products that could fulfill the functions of the traditional toothbrush. Second, it includes attention to various aspects of the process of "design," broadly defined. For example, one segment explores the environmental implications of product design and stimulates viewers to consider more fully what happens to a product after it is disposed of. In another segment, IDEO founder David Kelley explains how the scope of the design advice solicited by corporate clients has expanded over the course of his career.

I have used these and other segments of the film to introduce students to specific ideas and processes (e.g., ideation, product design) as well as to help students focus their attention on the ways in which the experience of product users can be enhanced or diminished by specific decisions that get made as the product is developed. These lessons are especially relevant to the design of tangible new products, but they are also relevant to conveying more general lessons (e.g., the importance of having empathy for one's customer) that are relevant to entrepreneurship in a wide range of contexts. For these reasons, among others, the film could be of use to undergraduate or graduate students in courses on entrepreneurship, innovation, marketing and related areas.
College business professors looking for more ideas to enrich the classroom experience can find them here (https://eiexchange.com/eix-in-class) .

Additional Search Terms: entrepreneurship courses, teaching ideas, teaching resources, classroom ideas, entrepreneurship classes, business schools, business school classes, entrepreneurship students, professors

\section{More ideas}

